\title{
Desain Interior Badan Perpustakaan Dan Kearsipan Provinsi Jawa Timur Dengan Pemanfaatan Budaya Lokal Modern
}

\author{
Desiree Eriyanti Suprapto, Nanik Rachmaniyah \\ Jurusan Desain Interior, Fakultas Teknik Sipil dan Perencanaan (FTSP),Institut Tekhnologi Sepuluh \\ Nopember (ITS) \\ JL. Arief Rahman Hakim, Surabaya 6011 Surabaya, Indonesia \\ Email: nanik.rachmaniyah@interior.its.ac.id
}

\begin{abstract}
Abstrak - Di jaman modern seperti saat ini terjadi fenomena persaingan antar individu di masyarakat agar tidak tertinggal dengan perkembangan arus globalisasi yang sangat pesat. Masyarakat dituntut untuk memiliki skill dan pengetahuan yang luas yang dapat didapat dari internet, buku dan majalah. Kebutuhan akan pendidikan menjadikan sebagai kebutuhan primer bagi masyarakat. Untuk memperoleh pendidikan formal tidak hanya dapat didapatkan di sekolah ataupun dari bimbingan belajar, tetapi dapat diperoleh di perpustakaan. Tetapi sayangnya kesadaran masyarakat kurang meminati pentingnya membaca buku sehingga dibutuhkan perubahan konsep desain pada perpustakaan untuk menarik minat masyarakat untuk datang dan membaca buku. Salah satu yang menjadi daya tarik pengunjung yaitu memberikan fasilitas yang lengkap, area baca semi outdoor dan lain lain. Dalam hal ini dengan penambahan area baca semi outdoor dapat memberikan daya tarik tersendiri bagi perpustakaan agar pengunjung dapat santai mengerjakan tugas ataupun membaca buku. Terdapat beberapa faktor kenyamanan serta keamanan pada fasilitas pada perpustakaan yang dapat mempengaruhi sisi psikologis pada pengunjung untuk memberikan daya tarik bagi pembacanya. Pemilihan furnitur yang multifungsi dapat meminimalisirkan banyaknya jenis furnitur yang akan memberikan kesan sempit pada ruangan. Metode desain yang digunakan meliputi pengumpulan data yang dilaksanakan secara langsung maupun tidak secara langsung seperti pembagian kuisioner pada pengunjung perpustakaan. Studi pustaka yang diambil banyak didapat dari internet, dan majalah yang berhubungan dengan kontemporer serta mendalami budaya Jawa Timur untuk mendukung konsep perpustakaan yang akan di redesain. Hasil yang diharapkan dari desain interior ini adalah merancang desain interior perpustakaan sebagai sarana edukasi dan hiburan yang dapat meningkatkan minat baca dan kreatifitas masyarakat luas.
\end{abstract}

Kata Kunci- Budaya Lokal Jawa Timur, Kontemporer, Perpustakaan

\section{PENDAHULUAN}

$\mathrm{P}$ ENDIDIKAN merupakan kebutuhan utama bagi pelajar untuk menambah wawasan dan pengetahuan serta mengasah kreativitas dalam berpikir. Setiap manusia berhak mendapatkan pendidikan dan pengajaran secara formal maupun informal. Namun pendidikan secara formal dimulai saat usia anak mencapai usia 5 tahun dan baru meduduki sekolah di taman kanak-kanak (TK), dari TK pendidikan berlanjut ke SD, SMP, SMA hingga mencapai bangku perkuliahan. Pada masa perkuliahan, mahasiswa dituntut untuk menggali ilmu pengetahuan yang lebih dalam, salah satu cara untuk mendapatkannya yaitu dengan cara membaca. Untuk memenuhi kebutuhan mahasiswa akan hal itu maka dibutuhkan sebuah perpustakaan yang memiliki fasilitas yang lengkap dan dapat mempermudah kebutuhan pengunjung selama di perpustakaan. Sasaran perpustakaan yang paling diminati oleh pengunjung Surabaya adalah perpustakaan Provinsi Jawa Timur yang memiliki literatur yang cukup lengkap serta memiliki beberapa fasilitas yang cukup memadai. Letak perpustakaan yang strategis serta didukung dengan fasilitas pendukung lainnya dapat memberikan daya tarik tersendiri bagi perpustakaan tersebut.

Badan Perpustakaan Provinsi Jawa Timur merupakan salah satu perpustakaan di Surabaya yang akan dijadikan objek dalam Tugas Akhir ini, sekaligus perolehan konsep Kontemporer dengan unsur muatan lokal dan berorientasi pada penunjang pendidikan di Surabaya. Badan Perpustakaan Provinsi Jawa Timur berlokasi di Jl. Menur Pumpungan 32, Surabaya.

Desain interior Badan Perpustakaan Provinsi Jawa Timur bertujuan untuk memberikan kemudahan bagi pengunjung dengan menciptakan desain yang modern dan informatif sehingga dapat memunculkan desain baru yang dapat menjadikan Perpustakaan Jawa Timur sebagai perpustakaan utama yang paling diminati oleh pengunjung.

Pelaksanaan desain ini membutuhkan pengamatan berupa survey lapangan, wawancara langsung dengan responden serta pengumpulan data dan referensi perpustakaan yang di dapat dari situs internet. Perpustakaan sangat kental dengan tempat yang sangat membosankan, monoton dan memiliki fasilitas yang terbatas sehingga dengan mengetahui kelemahan perpustakaan sehingga pengunjung yang datang mereka cenderung bosan. Berdasarkan keinginan untuk menarik minat pengunjung untuk datang ke perpustakaan maka pimpinan perpustakaan memberikan fasilitas tambahan berupa area wifi serta penambahan fasilitas baca outdoor. Hasil dari desain tersebut dapat memberikan solusi baru untuk kebutuhan pengguna Badan Perpustakaan Provinsi Jawa Timur. Dengan demikian hasil yang adapun dapat memenuhi kebutuhan serta dapat memberikan daya tarik bagi pengunjung. 


\section{A. Tujuan}

Adapun beberapa tujuan dan manfaat yang ingin dicapai dari desain interior Badan Perpustakaan Propini Jawa Timur, meliputi :

1. Menciptakan inovasi desain interior yang nyaman dan tidak monoton sehingga dapat meningkatkan minat pembaca untuk membaca di perpustakaan.

2. Menciptakan area semi outdoor dengan adanya taman kecil yang difungsikan untuk menghindari kesan tegang pada perpustakaan.

3. Menciptakan layout dan zoning area yang baik pada interior perpustakaan, sehingga mampu meberikan kenyamanan dan sirkulasi bagi pengunjung dan staf.

\section{B. Manfaat}

1. Manfaat bagi perpustakaan

Eksistensi perpustakaan semakin meningkat karena memiliki desain interior yang nyaman serta tidak memberikan kesan monoton pada ruangan sehingga pembaca dapat betah berlama-lama di perpustakaan.

2. Manfaat bagi konsumen

Melengkapi dengan kebutuhan konsumen yang dapat menunjang aktivitas mereka dengan adanya pengembanan fungsi ruang dan suasana.

\section{Rumusan Masalah}

1. Bagaimana menciptakan konsep desain yang dapat menarik minat pembaca untuk meningkatkan profit perpustakaan?

2. Bagaimana cara memaksimalkan fungsi ruang sehingga dapat menciptakan ruang yang mendukung dengan aktifitas pembaca?

3. Bagaimana menciptakan konsep desain perpustakaan di tengah mobilitas perkotaan yang santai?

\section{METODE PENELITIAN}

\section{A. Metode Pengumpulan Data}
1. Observasi
2. Depth Interview
3. Kuisioner

\section{B. Analisis Data}

Metode yang digunakan dalam pengolahan data adalah dengan cara mengunakan metode induktif, yaitu dengan cara mengumpulkan semua data yang ada kemudian dianalisis berdasarkan literatur dan kemudian diambil kesimpulannya.

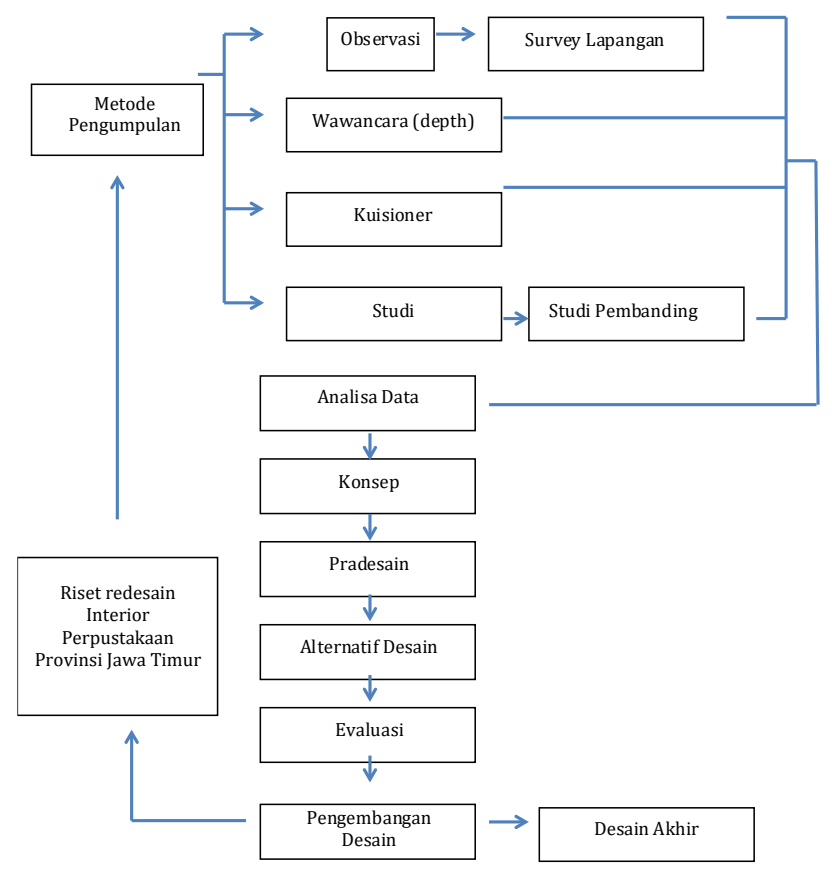

Bagan 1. Metode Desain

\section{KONSEP DESAIN}

Berikut ini pengaplikasian konsep pemanfaatan budaya local modern untuk perpustakaan pada objek desain:
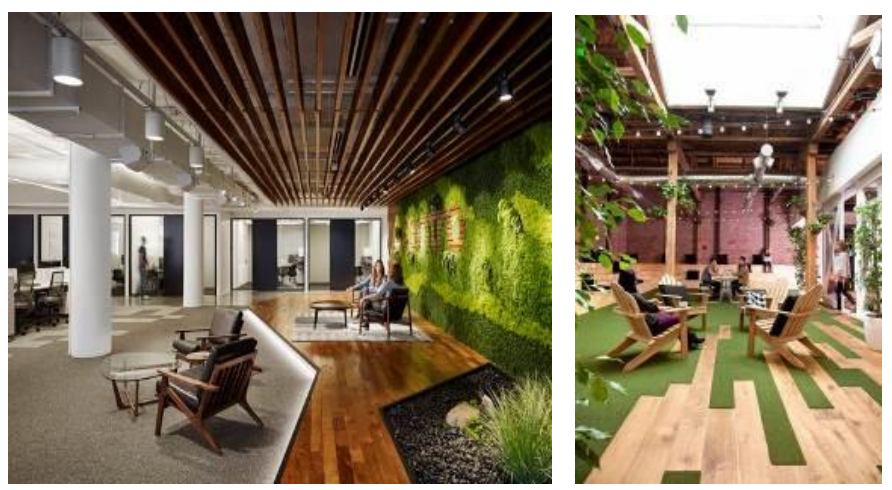

Gambar 1. Konsep bentuk (a) Konsep bentuk (b)

\section{A. Konsep Bentuk}
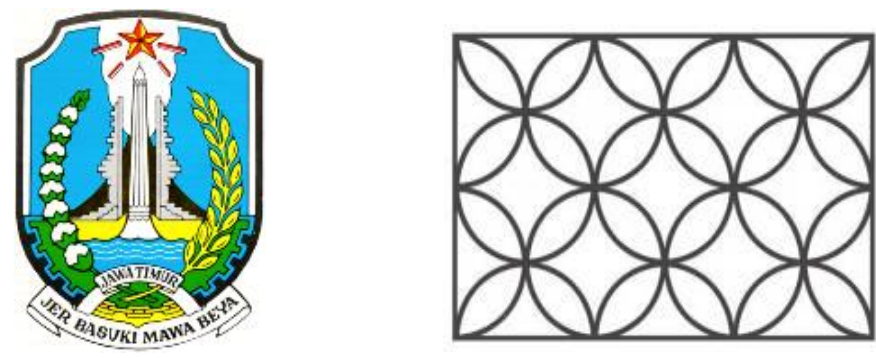

Gambar 2. Konsep bentuk (a) Konsep bentuk (b) 
Pemilihan bentuk kawung dikarenakan memiliki filosofi yang bagus dan diharapkan filosofi tersebut dapat memberikan dampak positif pada perpustakaan. Selain itu, batik kawung juga memiliki bentuk yang menarik serta mudah untuk diaplikasikan dengan berbagai macam warna.

\section{B. Konsep Warna}
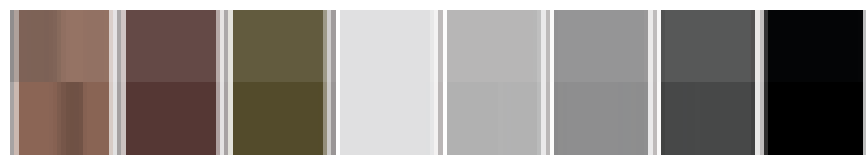

Gambar 3. Konsep warna

Untuk menonjolkan karakteristik perpustakaan maka suasana perpustakaan dibuat semenarik mungkin sehingga menarik minat pengunjung yang datang. Warna paling dominan yang dipilih adalah warna abu-abu muda karena warna ini merupakan warna netral yang dapat dikombinasikan dengan macam warna. Selain itu warna ini juga memberikan kesan clean.

\section{Konsep Material}

Jenis material yang digunakan yaitu material kayu jati londo dan keramik dengan ukuran 80x80 warna abu-abu tua yang dapat memberikan volume pada ruangan. Selain itu sebagai point of view dengan menampilkan unsur budaya lokal yaitu dengan memberikan sentuhan laser cut batik pada tiang kolom dinding.

\section{Konsep Furnitur}

Penggunaan furnitur yang dapat memberikan kenyamanan bagi pengunjung serta memberikan kesan modern. Pemilihan jenis kursi yang digunakan yaitu untuk menghindari kesan monoton pada ruangan, sehingga pemilihan kursi dengan konsep kafe dapat memberikan kesan santai. Selain itu untuk nuansa outdoor dapat memberikan kesan santai saat pengunjung membaca di area baca tersebut serta tidak akan merasa jenuh karena terdapat rumput syntetis.

\section{E. Konsep Dinding}

Pada konsep dinding yang akan diaplikasikan pada perpustakaan yaitu dengan pemilihan warna abu-abu tua untuk area baca formal. Sedangkan pada area baca semi outdoor menggunakan 3 jenis material, yaitu warna abu-abu dengan finishing semen yang dikombinasikan dengan warna putih. Dan untuk area foyer menggunakan konsep kamport dengan kombinasi tali air yang dapat mendukung nuansa outdoor.

\section{HASIL AKHIR}

Bentuk lantai yang disama ratakan yakni material semen abu muda tekstur halus agar pengunjung lebih bebas bereksplorasi. Bentuk geometris segi empat diterapkan pada bentuk rak buku secara acak sebagai point of interest ketika mencari buku.

Material besi dengan paduan warna putih dan akrilik motif batik menghasilkan kombinasi local modern yang tepat. Warna tosca dan hijau muda merupakan warna yang dapat menarik pengunjung dan jenis warna tersebut dapat menghidupkan suasana di perpustakaan agar tidak terkesan monoton. Pencahayaan lampu yang menyebar keseluruh ruangan sangat baik untuk area membaca agar pengguna lebih nyaman.

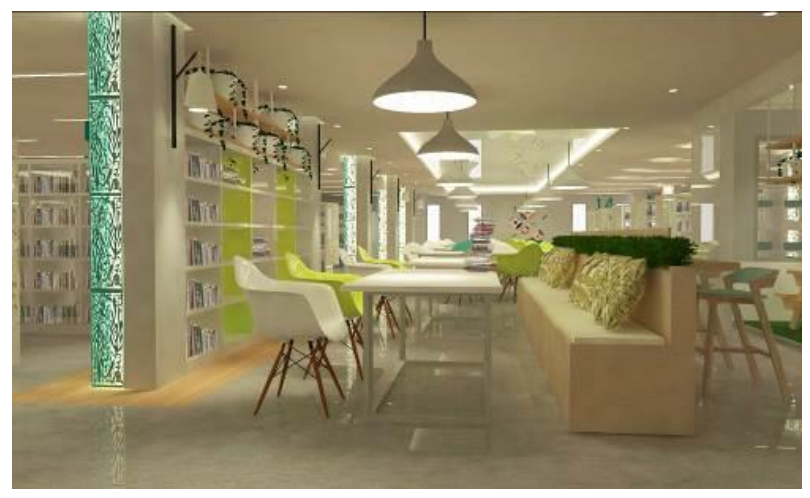

Gambar 5. Tampak 3D area baca

Pada area baca bersama terdapat pengkombinasian antara meja belajar kelompok dan individu dalam satu furnitur yang sama. Pemisahan antara area baca individu dan area baca bersama terletak pada tingginya jenis tanaman dan terdapat penyekat sehingga pengunjung di area individu tidak akan merasa terganggu. Pemilihan jenis kursi yang santai menjadi daya tarik tersendiri sehingga pengunjung tidak akan merasa bosan selama di perpustakaan.
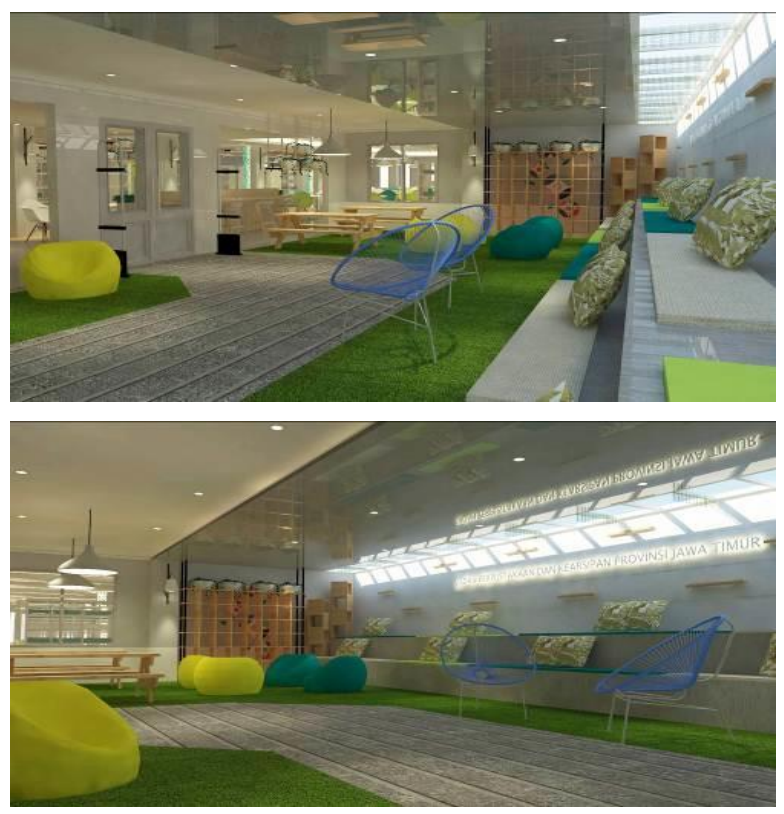

Gambar 4. Tampak 3D area baca semi Outdoor

Area baca semi outdoor ini sengaja dirancang untuk meningkatkan energi para pembaca agar tidak merasa monoton di dalam ruangan. Selain itu pemilihan warna warna alam dapat mengurangi tingkat kejenuhan pengunjung saat melakukan aktifitas di perpustakaan. Selain itu dengan adanya void kaca dapat memberikan akses cahaya alami dan dapat menghemat biaya listrik. 

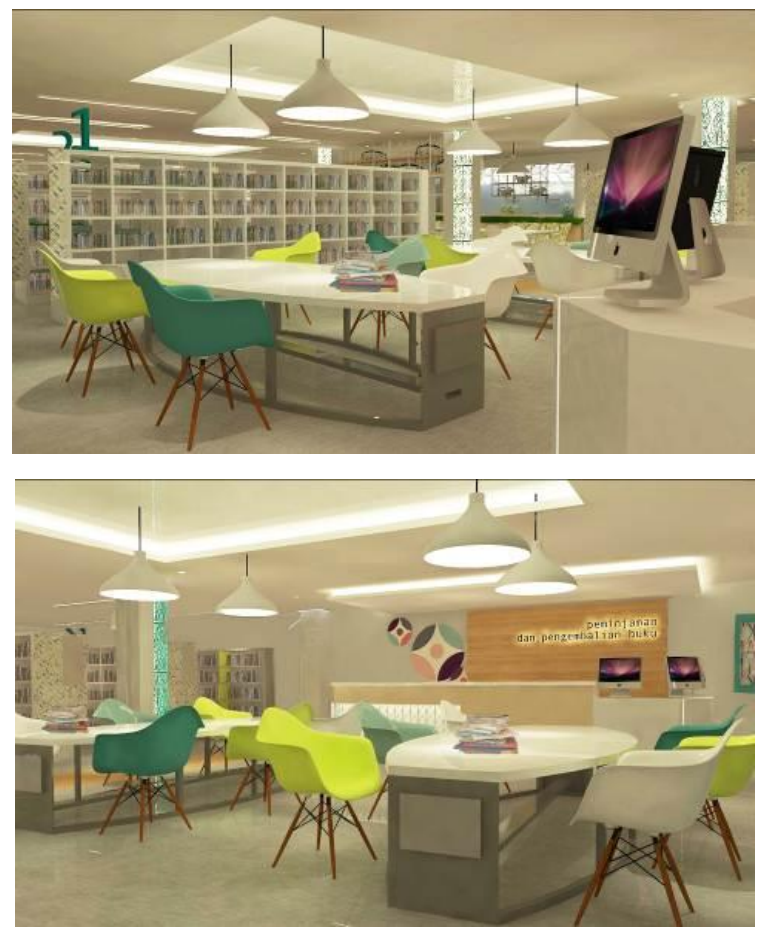

Gambar 6. Tampak 3D area pelayanan

Pada area pelayanan ini terdapat bacdrop yang menggunakan material kayu yang dapat memberikan kesan hangat pada perpustakaan. Selain itu terdapat aksen mural batik kawung untuk mengentalkan budaya Jawa ke dalam perpustakaan.

\section{KESIMPULAN/RINGKASAN}

1. Badan Perpustakaan dan Kearsipan Provinsi Jawa Timur ini cukup dikenal oleh masyarakat Surabaya, akan tetapi dibutuhkan konsep desain baru yang menarik untuk perpustakaan agar tidak terkesan monoton sehingga dapat meningkatkan minat pengunjung untuk membaca diperpustakaan.

2. Segmentasi masyarakat terutama pada mahasiswa yang membutuhkan fasilitas pendukung lainnya diharapkan terdapat penambahan fasilitas yang dapat menunjang demi memenuhi kebutuhan pengunjung agar pengunjung dapat nyaman di perpustakaan tersebut.

3. Menampilkan desain interior dengan ciri khan visi dan misi Badan Perpustakaan dan Kearsipan dengan sentuhan modern dan muatan local sehingga pengunjung tidak akan merasa jenuh selama di perpustakaan.

\section{DAFTAR PUSTAKA}

[1] Saleh. dkk. Pengelolaan Terbitan Berseri. Jakarta: Universitas Terbuka. (1996)

[2] Darmono. Manajemen dan Tata Kerja Perpustakaan Sekolah. Jakarta: PT. Gramedia Widiasarana Indonesia. (2001)

[3] Sulistiyo Basuki. Pengantar Ilmu Perpustakaan. Jakarta: Universitas Terbuka. (1993) 